\title{
Promotion Incentive, Employee Satisfaction and Commercial Bank Performance
}

\author{
Zequn Chen \\ Business School, Nanjing Normal University, Nanjing, China \\ Email: chenzequnsy@163.com
}

How to cite this paper: Chen, Z. Q. (2020). Promotion Incentive, Employee Satisfaction and Commercial Bank Performance. Open Journal of Social Sciences, 8, 108-123. https://doi.org/10.4236/jss.2020.84008

Received: March 16, 2020

Accepted: April 7, 2020

Published: April 10, 2020

Copyright $\odot 2020$ by author(s) and Scientific Research Publishing Inc. This work is licensed under the Creative Commons Attribution International License (CC BY 4.0).

http://creativecommons.org/licenses/by/4.0/

\begin{abstract}
Taking employee satisfaction as the mediating variable, this paper explored the relationship between promotion incentives, employee satisfaction and performance of Chinese commercial Banks by constructing a game model, and took 30 listed commercial banks from 2009 to 2018 as samples to empirically test the conclusions. Research shows that promotion incentive can significantly improve the performance of commercial Banks, and this incentive effect is more significant in state-owned commercial Banks. Further research shows that employee satisfaction plays a part in mediating between promotion incentive and performance of commercial Banks, that is, promotion incentive can improve performance of commercial Banks by improving employee satisfaction. The research conclusion enriches the research on the path of promotion incentive on the performance of commercial Banks and provides some inspirations for the design of incentive schemes for employees of commercial Banks.
\end{abstract}

\section{Keywords}

Promotion Incentive, Employee Satisfaction, Commercial Bank Performance

\section{Introduction}

The banking industry is an important part and core industry of the national economic system. The bank outlets all over the country have mastered over $90 \%$ of the financing needs and deposit and loan settlement needs of the country. The performance of commercial Banks not only affects the development of Banks themselves, but also reflects the level of social resource allocation. In recent years, scholars have done a lot of research on the factors affecting the performance of commercial Banks and divided the factors into two aspects: internal factors and external factors. In general, the external factors are mainly divided 
into three aspects: macro policy, banking structure and financial structure. However, the study of influencing factors in the banking industry is slower than that of companies in the general industry. By learning from and developing the study of companies in the general industry, it is mainly carried out from two aspects: bank governance (Liu et al., 2012) and employee incentive (Shen \& Lin, 2012; Zhang et al., 2016). Among them, the important influence of employee incentive on the performance of commercial Banks has been confirmed by many studies.

With the development of economic globalization, modern enterprises at home and abroad have been continuously integrated into the international management mode, and the equity investment method has been deeply integrated into the enterprise management. The relationship between enterprise shareholders and professional managers is no longer a pure "superior and subordinate" relationship, but an "agent" relationship. In this way, once the balance of interests between the two is broken, managers' "betrayal" of shareholders may occur, which will cause a great loss of interests to enterprises and shareholders. Meanwhile, the turnover of executives in the managers will also send bad information to the market and affect the normal operation of commercial Banks. So through a variety of incentives, including equities, salary, promotion, rewards, let the high-end professional managers and enterprises establish a "community of destiny", so that they gain a sense of accomplishment and happiness, can better avoid the deviation behavior of executives, promote their dedicated enterprise innovation reform, and improve the core competitiveness of state-owned commercial Banks.

To retain talents and improve the performance of commercial Banks, it is imperative to study the sense of belonging of employees. The purpose of Schein psychological contract management is to increase employees' job satisfaction through human resource management, so as to realize employees' sense of belonging to the organization and their high involvement in the work. Maslow (1943) and Hertzberg (1959) believe that money is only an effective incentive factor to some extent. Once employees' low-level needs are satisfied, they will be motivated by non-monetary factors, such as job satisfaction, which cannot be purchased with money from the outside but can only be provided by the company. Therefore, job satisfaction is an effective form of compensation.

Based on this, this paper starts from the psychological contract theory, through the construction of the game model, in-depth research and analysis of promotion incentive on bank performance mechanism, and empirical test of the conclusion. In addition, by studying the mediating and regulating effects of employee satisfaction on promotion incentives and performance of commercial Banks, it provides theoretical guidance for commercial Banks to motivate senior executives to improve performance. The other parts of this paper are arranged as follows: the second part is a review of the existing research and a summary of the previous research. The third part constructs the theoretical model and the economic model. The fourth part uses the model empirical analysis to verify the effectiveness of the model, and discusses the meaning of the model. The fifth part 
is the conclusion and future prospect of this research.

\section{Literature Review}

\subsection{Promotion Incentives and Bank Performance}

As an important psychological contract, promotion incentive can not only select talents, but also improve the enthusiasm of employees to serve enterprises. Such enthusiasm plays an indispensable role in improving the performance of Banks and promoting the long-term development of commercial Banks. Yu \& Zhang (2016) found that promotion incentive is a more effective way to motivate employees than salary incentive and equity incentive.

Lazar \& Rosen's championship theory (1981) has always occupied a mainstream position in the literature on the relationship between promotion incentive and bank performance. It realizes the incentive effect by comparing the performance of agents, rewarding those with higher performance and punishing those with lower performance. On the basis of the championship theory, some scholars in China have found that under the influence of promotion incentives, senior executives will improve enterprise performance through mergers and acquisitions, reduce on-the-job consumption and other ways. At the level of Banks, Liu et al. (2015) studied the impact of promotion incentives on the performance of Banks with different property rights by selecting the panel data of China's listed commercial Banks over 5 years, and concluded that promotion incentives have a significant positive effect on the performance of state-owned Banks. Corresponding to the tournament theory is the behavior theory.

However, Milgrom \& Roberts (1992) stressed that the gap cannot motivate employees to make more efforts. On the contrary, narrowing the salary gap can weaken the members' psychology of keeping up with the jawing, promote teamwork, and thus improve enterprise performance. Similarly, on the basis of the political interference hypothesis, Shen \& Lin (2012) explains that political factors can inhibit the performance of government Banks, and that the inhibiting effect is more significant in developing countries. Zhang et al. (2016) found that the promotion of bank executives could not increase the performance of Banks through empirical research from China. This paper proposes the first hypothesis that promotion incentive plays a positive role in promoting the growth of bank performance.

In addition, the effect of promotion incentives may be affected by the nature of property rights. Zhou \& Zhang (2016) thinks that compared with non-state-owned Banks, the executives of state-owned commercial Banks in China cannot set excessive salary for themselves due to more government regulation, public attention, and restrictions on salary. At this time, they will pursue hidden rewards such as job promotion to obtain psychological satisfaction. Similarly, Xu (2012) proposed through his research on two types of enterprises with property rights that the executives of state-owned enterprises have a stronger sense of promotion incentives and are more likely to make decisions conducive to the develop- 
ment of the company. Therefore, this paper argues that promotion incentive plays a greater role in promoting the performance of state-owned Banks than that of non-state-owned Banks. Therefore, this paper proposes the second hypothesis that promotion incentive plays a greater role in promoting the performance of state-owned Banks than that of non-state-owned Banks.

\subsection{Mediating Effect of Employee Satisfaction}

The core of Schein's psychological contract theory is employee satisfaction. Enterprises enhance employee satisfaction through human resource management, so that employees can maintain a high sense of belonging to the organization, and then increase their efforts to improve corporate performance. Hall \& $\mathrm{Ny}$ gren (1970) has proposed "when individual goals match the enterprise goals, the sense of belonging is produced", employees sense of belonging is due to a combination of both material and spiritua ( $\mathrm{Li}, 2009)$, make an individual to a whole fooled and sense of belonging, which makes the individual active integrate into a whole, to act as his starting point and the foothold of overall interests. While satisfaction with the work unit is the premise for employees to have a sense of belonging. Whether to improve employee satisfaction is the key to win employees' loyalty and enhance the cohesion and competitiveness of the enterprise.

From the perspective of psychological contract theory, employee satisfaction has a positive effect on the performance of commercial Banks by improving their efforts, which has been confirmed by domestic and foreign literatures. Edmans (2011) studied the relationship between employee satisfaction and long-term stock returns through value weighting of "the 100 most suitable companies for work in the United States", and the results showed that employee satisfaction was positively correlated with shareholder returns. Wang \& Kim (2013), by studying the behavior of employees in Chinese enterprises, concluded that employees with high satisfaction with enterprises tend to engage in active social behaviors to improve the performance of enterprises or Banks. Xie et al. (2019) issued questionnaires to employees of Internet enterprises and made empirical analysis based on the collected information to obtain the positive correlation between employee satisfaction and enterprise performance.

At the same time, promotion incentive can also promote the improvement of employee satisfaction. The salary incentive in employee incentive is the equivalent salary return for employees' efforts and the embodiment of employee value. However, Kohn (1993) believes that the output-based incentive may be ineffective or even destructive. Promotion incentive is a spiritual factor. In a society with increasingly rich material life, employees' pursuit of personal development is far more than their demand for material materials. Promotion incentive not only enables employees to identify with the development concept of the enterprise, but also to appreciate the cultivation of the organization, so as to generate greater willingness to reward the enterprise (Maslow, 1943; Herzberg, 1959). Therefore, promotion incentive, as an important psychological contract, can not 
only increase the enthusiasm of employees, but also enhance their sense of belonging and identity. Therefore, this paper proposes the hypothesis that employee satisfaction plays an intermediary role in the promotion incentive affecting the performance of commercial Banks.

\section{Methodology}

\subsection{Theoretical Analysis}

Based on the principal-agent theory, this paper constructs a simple static game model with incomplete information to verify the relationship between promotion incentives and the performance of commercial Banks. Assuming that the output of commercial bank executives is proportional to their efforts. From this, build the linear model:

$$
y=k x+\varepsilon, \varepsilon \sim N\left(0, \sigma^{2}\right)
$$

where $y$ stands for output, $x$ represents the effort level of the executives, and $k$ represents the ability level.

Suppose that the effort cost of the executive is $c(x)$, and the cost increases with the effort of the executive, $c^{\prime}(x)>0$, And the cost increases quickly, $c^{\prime \prime}(x)>0$. Therefore, this paper assumes that the cost function is $c(x)=t x^{2} / 2$, and $t$ is the effort cost coefficient of executives. $w=w_{0}+\beta y$, where $w_{0}$ represents fixed compensation, and $\beta y$ represents incentives for executives (including promotion incentives and compensation incentives, etc.), which are positively correlated with output $(\beta>0)$. Among them, the symbol of $\beta$ incentive coefficient. From this you can derive the actual pay of the executives:

$$
I=w-c(x)=w_{0}+\beta(k x+\varepsilon)-t x^{2} / 2
$$

The agent is generally risk-averse, and its utility function is assumed to be $U=-\mathrm{e}^{-r I}$. At this point, the agent's deterministic utility is:

$$
U(E(I)-\pi)=U(E(I)-\rho \operatorname{var}(w) / 2)=U\left(w_{0}+\beta k x-\frac{t x^{2}}{2}-\frac{\rho \beta^{2} \sigma^{2}}{2}\right)
$$

where, $\rho$ is the absolute risk aversion coefficient, $\rho=-U^{\prime \prime} / U^{\prime}$. We know that the utility function for risk-averse people is a strictly concave function, where $U^{\prime}>0$ and $U^{\prime \prime}<0$. To maximize the agent's deterministic utility, we have to maximize $E(I)-\pi$,

$$
x=\beta k / t
$$

Formula (4) shows that under the condition that the executive's ability and effort cost remain unchanged, the executive's effort level is directly proportional to the incentive coefficient, and the output and bank performance also increase with the executive's effort level. In contrast, the client hopes to get the maximum profit with the minimum cost, and the salary paid and the incentive to the executives are the costs that the client faces, so the client expects the profit to be:

$$
E(y-w)=-w_{0}+(1-\beta) k x
$$


If the agent's actual income $I$ is less than the expected utility $U$, the agent will be engaged in other work, and $U \geq I$ is a necessary condition. To maximize the expected revenue on the basis of maximizing the agent's income, the following mathematical model is constructed:

$$
\begin{gathered}
\max . E(y-w)=-w_{0}+(1-\beta) k x \\
\text { s.t. } R \geq I,-\frac{\rho \beta^{2} \sigma^{2}}{2} \geq \beta \varepsilon \\
\text { s.t. } x=\beta k / t
\end{gathered}
$$

From the above formula, the Lagrangian function is constructed:

$$
\beta=k^{2} /\left(k^{2}+t \rho \sigma^{2}\right)
$$

where, $\beta>0$, which means that in the case of information asymmetry, the principal's incentive to the agent is a necessary condition to maximize the profit of commercial Banks.

\section{Mediating Effect of Employee Satisfaction}

Assuming that employee satisfaction is proportional to the degree of effort for executives, and build a linear model, namely $x=s m+\epsilon, \epsilon \sim N\left(0, \delta^{2}\right)$. Where, $s$ represents the degree of employees' satisfaction with the work unit, and $m$ is the conversion coefficient of employee satisfaction. Substitute $s$ into Equation (3), and the deterministic utility of the agent is:

$$
U(E(I)+E(s)-\pi)=U\left(w_{0}+\beta k x-\left(t x^{2}\right) / 2+s-\left(\rho \beta^{2} \sigma^{2}+\rho \delta^{2} / m^{2}\right) / 2\right)
$$

To maximize the utility of the agent,

$$
s=(\beta k m+1) / \mathrm{tm}^{2}
$$

Formula (7) shows that, under other conditions unchanged, the satisfaction of senior executives increases with the increase of incentives, and the efforts of senior executives are also in a direct proportion to the satisfaction. Thus, the positive promotion relationship between satisfaction and the efforts of senior executives and bank performance can be obtained.

\subsection{Econometric Model Setting}

Previous literature studies have shown that in addition to promotion incentives, salary incentives and banking characteristics can also affect the performance of commercial Banks, and banking characteristics include bank Size (Size), bank listing Time (Time), non-performing loan ratio (NPL), capital adequacy ratio (CAR) and asset-liability ratio (LEV). Different from ordinary enterprises, equity incentive is almost not allowed in China's state-owned commercial Banks, so equity incentive is not controlled. Considering a variety of factors, the following Econometric model is set in this paper:

$$
\begin{aligned}
\text { Roa }= & \beta_{0}+\beta_{1} \mathrm{PP}+\beta_{2} \mathrm{NPL}+\beta_{3} \text { Size }+\beta_{4} \text { Time }+\beta_{5} \mathrm{CAR}+\beta_{6} \text { fwage } \\
& +\beta_{7} \text { lev }+\beta_{8} \text { state }+\beta_{9} \text { state } * \mathrm{PP}+\sum \text { year }+\varepsilon
\end{aligned}
$$




$$
\begin{aligned}
\text { Sat }= & \delta_{0}+\delta_{1} \text { PP }+\delta_{2} \text { NPL }+\delta_{3} \text { Size }+\delta_{4} \text { Time }+\delta_{5} \text { CAR }+\delta_{7} \text { fwage } \\
& +\delta_{8} \text { lev }+\delta_{9} \text { state }+\delta_{10} \text { PP } * \text { state }+\varepsilon \\
\text { Roa }= & \theta_{0}+\theta_{1} \text { Sat }+\theta_{2} \text { NPL }+\theta_{3} \text { Size }+\theta_{4} \text { Time }+\theta_{5} \text { CAR }+\theta_{7} \text { fwage } \\
& +\theta_{8} \text { lev }+\theta_{9} \text { state }+\theta_{10} \text { Sat } * \text { state }+\varepsilon
\end{aligned}
$$

Model (8) examines the impact of promotion incentives on the performance of commercial Banks. Model (9) (10) investigated the mediating effect of employee satisfaction on promotion incentives and performance of commercial Banks. In equation (8), return on assets (ROA) is used as a measure of the performance of commercial Banks, because ROA can fully reflect the good effect achieved by commercial Banks in the efficiency of capital utilization. PP represents the annual promotion incentive intensity of each bank, which can be obtained by logit regression with the following model:

$$
\text { Pro }_{i, t}=\alpha_{0}+\alpha_{1} \text { Character }+\alpha_{2} \text { ROA }+\alpha_{3} \text { Bank }+\mu_{i t}
$$

where, Pro $_{i, t}$ is the dummy variable of whether the executive actually gets promoted or not. When the executive is actually promoted, the value is assigned to 1 . Character represents the personal characteristics of senior executives, including variables such as Age, educational background (Edu), Wage and expected tenure of senior executives (Etenture). The expected tenure is calculated by the sum of the retirement age of senior professional titles and the average length of service of senior executives in the industry minus the actual age and length of service of senior executives. ROA is the performance measurement index of enterprises. It is obvious that performance can affect the promotion probability of senior executives. Finally, Bank represents the characteristics of the Bank, and measures include Size, Time to market, NPL, CAR, LEV, Num, etc. The variable description is shown in Appendix Table A1.

\subsection{Data Sources}

In this paper, 30 Chinese Banks listed on the a-share market in 2009 and later were selected as samples. The data mainly came from CSMAR, and the employee satisfaction data came from Zhaopin.com's "China's best employers of the year" list. The promotion of senior executives and some missing data are supplemented by manually thumbing through the annual reports of listed Banks. The data processing and model building is done in Stata14.

\section{Empirical Results and Discussion}

\subsection{Descriptive Statistics}

As shown in Table 1, the mean value of promotion incentive is positive in both Chinese state-owned and non-state-owned commercial Banks, indicating that promotion incentive is prevalent in commercial Banks in China, while the average promotion incentive intensity of state-owned commercial Banks is 0.068 greater than that of non-state-owned industrial Banks 0.053. The average performance of state-owned commercial Banks is 0.011 , which is higher than that of 
Table 1. Descriptive statistics.

\begin{tabular}{cccccccccccc}
\hline \multicolumn{4}{c}{ non-state-owned commercial Banks } & \multicolumn{5}{c}{ state-owned commercial Banks } \\
\hline Name & Number & Standard & mean & $\max$ & $\min$ & Number & Standard & mean & max & min \\
\hline ROA & 95 & 0.002 & 0.009 & 0.013 & 0.005 & 64 & 0.002 & 0.011 & 0.014 & 0.007 \\
PP & 95 & 0.025 & 0.053 & 0.128 & 0.013 & 64 & 0.023 & 0.068 & 0.131 & 0.029 \\
Sat & 95 & 0.448 & 0.274 & 1.000 & 0.000 & 64 & 0.333 & 0.125 & 1.000 & 0.000 \\
NPL & 95 & 0.005 & 0.012 & 0.025 & 0.004 & 64 & 0.004 & 0.013 & 0.024 & 0.006 \\
Size & 95 & 3.120 & 12.43 & 15.72 & 6.701 & 64 & 0.766 & 16.01 & 17.14 & 14.37 \\
Time & 95 & 1.026 & 1.800 & 3.332 & 0.000 & 64 & 0.454 & 2.067 & 2.833 & 0.693 \\
CAR & 95 & 0.016 & 0.116 & 0.157 & 0.082 & 64 & 0.041 & 0.138 & 0.443 & 0.106 \\
Fwage & 95 & 4.400 & 6.751 & 22.57 & 2.146 & 64 & 3.456 & 5.143 & 13.76 & 1.640 \\
LEV & 95 & 0.010 & 0.934 & 0.952 & 0.903 & 64 & 0.008 & 0.930 & 0.950 & 0.914 \\
\hline
\end{tabular}

non-state-owned commercial Banks. In terms of employee satisfaction, the average value of non-state-owned commercial Banks is 0.274, which is much higher than that of state-owned commercial Banks. There is a large gap in inter-bank executive compensation, with a minimum value of 1.64 million yuan and a maximum value of 22.569 million yuan, which means that the compensation incentive intensity of different commercial Banks varies greatly. From the perspective of other statistical variables, the size, time of listing and capital adequacy ratio of each commercial bank are significantly different. In terms of bank size, the logarithm of the average size of state-owned commercial Banks is 17.137 greater than that of non-state-owned commercial Banks, while the logarithm of the maximum bank size reaches 17.137 and the logarithm of the minimum value is only 6.701. There is also a large gap between the listing time of the two types of Banks. The average listing time of state-owned commercial Banks is 1.800, while that of non-state-owned commercial Banks is slightly higher (2.067). However, the non-performing loan ratio of the two types of Banks did not show a big difference; In terms of capital adequacy ratio, the average capital adequacy ratio of state-owned commercial Banks is 0.443, much higher than that of non-state-owned commercial Banks 0.116. Finally, the capital adequacy ratio of the two types of Banks is close to the number does not show a big gap.

\subsection{Correlation Analysis}

It can be seen from Table 2 that the performance of commercial Banks is positively correlated with promotion incentives, which is significant at the level of $10 \%$. It can be preliminarily judged that promotion incentives can promote the improvement of bank performance. At the same time, salary incentive has a positive driving effect on the performance of commercial Banks, but the result is not significant, and the correlation coefficient is also small. The effect of property right on bank performance is positive and significant at $1 \%$ level. Although the mediating effect of employee satisfaction is positive, it is not very significant, 
Table 2. Correlation analysis.

\begin{tabular}{cccccccccc}
\hline & ROA & PP & Sat & NPL & size & Time & CAR & Fwage & LEV \\
\hline ROA & 1 & & & & & & & \\
PP & $0.147^{*}$ & 1 & & & & & & \\
Sat & 0.076 & 0.117 & 1 & & & & & \\
NPL & $-0.473^{* * *}$ & $0.181^{* *}$ & -0.07 & 1 & & & & & \\
size & $0.524^{* * *}$ & $0.213^{* * *}$ & $-0.148^{*}$ & $-0.134^{*}$ & 1 & & & \\
Time & $0.251^{* * *}$ & $0.143^{*}$ & -0.003 & -0.103 & $0.775^{* * *}$ & 1 & & \\
CAR & $0.369^{* * *}$ & 0.062 & -0.053 & -0.113 & $0.318^{* * *}$ & $0.253^{* * *}$ & 1 & \\
Fwage & 0.002 & -0.093 & $0.229^{* * *}-0.274^{* * *}$ & 0.093 & $0.400^{* * *}$ & -0.033 & 1 & \\
LEV & 0.092 & -0.129 & -0.064 & $-0.506^{* * *}$ & $0.151^{*}$ & 0.102 & $-0.164^{* *}$ & $0.295^{* * *}$ & 1 \\
\hline
\end{tabular}

which will be verified in the later regression. The variance inflation factor test of the variable shows that the mean value of VIF is 3.12 and there is no multicollinearity in the model, which can be further tested.

\subsection{Pooled Regression}

According to the fixed-effect regression results in Table 3, the performance of commercial Banks is negatively correlated with the non-performing loan ratio and asset-liability ratio, and positively correlated with the capital adequacy ratio and bank size. However, although the correlation between performance and promotion incentive is positive, it is not significant. To explore the causes of this insignificance, this paper divides the samples into state-owned commercial Banks and non-state-owned commercial Banks on the basis of model 8. Inspection results, as shown in the model 8 of the 232 listed state-owned commercial Banks before the promotion probability variable coefficient is 0.0078 , and $5 \%$ significance level, and non-state-owned commercial Banks before the PP coefficient is 0.0060 , and $10 \%$ significance level, this suggests that the promotion effect of state-owned commercial Banks is greater than the non-state-owned commercial Banks, this also verify the above hypothesis 2 . At the same time, the compensation incentive effect of state-owned commercial Banks is larger than that of non-state-owned commercial Banks, but the coefficient is smaller. Vertical comparison shows that promotion incentive plays a greater role than salary incentive in both state-owned and non-state-owned commercial Banks. This regression result verifies the conclusion of previous scholars that promotion incentive is a more effective incentive method in state-owned commercial Banks compared with salary incentive in China.

\subsection{Mediation Effect Test}

From Table 4, we can draw the following conclusions. As for the mediating effect of employee satisfaction, the regression results of all samples of model 9 show that the coefficient of executive promotion probability relative to employee 
Table 3. Fixed effect regression.

\begin{tabular}{|c|c|c|c|}
\hline & \multicolumn{3}{|c|}{ ROA } \\
\hline & All the samples & $\begin{array}{l}\text { non-state-owned } \\
\text { commercial Banks }\end{array}$ & $\begin{array}{c}\text { state-owned } \\
\text { commercial Banks }\end{array}$ \\
\hline $\mathrm{PP}$ & $\begin{array}{c}0.0043 \\
(1.3)\end{array}$ & $\begin{array}{c}0.0078^{\star *} \\
(2.00)\end{array}$ & $\begin{array}{c}0.0060^{*} \\
(1.8)\end{array}$ \\
\hline NPL & $\begin{array}{l}-0.09^{* * *} \\
(-2.75)\end{array}$ & $\begin{array}{l}-0.21^{* * *} \\
(-3.90)\end{array}$ & $\begin{array}{l}-0.065 \\
(-1.43)\end{array}$ \\
\hline Size & $\begin{array}{l}0.0007 \\
(1.09)\end{array}$ & $\begin{array}{c}-0.0034 \\
(-2.66)\end{array}$ & $\begin{array}{c}-0.0024 \\
(-1.74)\end{array}$ \\
\hline Time & $\begin{array}{l}-0.0003 \\
(-0.94)\end{array}$ & $\begin{array}{l}-0.0002 \\
(-0.45)\end{array}$ & $\begin{array}{l}0.0002 \\
(0.41)\end{array}$ \\
\hline CAR & $\begin{array}{c}0.0010 \\
(0.51)\end{array}$ & $\begin{array}{c}-0.0049 \\
(-0.37)\end{array}$ & $\begin{array}{c}-0.0007 \\
(-0.42)\end{array}$ \\
\hline fwage & $\begin{array}{c}-0.0001 \\
(-1.78)\end{array}$ & $\begin{array}{l}0.0000 \\
(-0.88)\end{array}$ & $\begin{array}{l}0.0001 \\
(1.11)\end{array}$ \\
\hline LEV & $\begin{array}{l}-0.07^{\star * *} \\
(-5.06)\end{array}$ & $\begin{array}{c}-0.05^{\star * *} \\
(-2.97)\end{array}$ & $\begin{array}{c}-0.0619 \\
(-3.23)\end{array}$ \\
\hline State ${ }^{\star} \mathrm{PP}$ & $\begin{array}{c}-0.0014 \\
(-0.92)\end{array}$ & & \\
\hline Year & control & control & control \\
\hline cons & $\begin{array}{c}0.066^{\star * *} \\
(6.42)\end{array}$ & $\begin{array}{c}0.101^{\star * *} \\
(5.83)\end{array}$ & $\begin{array}{c}0.107^{\star * *} \\
(5.57)\end{array}$ \\
\hline $\mathrm{N}$ & 159 & 95 & 64 \\
\hline $\mathrm{F}$ & $31.92^{\star * *}$ & $13.87^{\star \star \star}$ & $39.67^{\star \star *}$ \\
\hline $\mathrm{R}-\mathrm{sq}$ & 0.8077 & 0.7669 & 0.9297 \\
\hline
\end{tabular}

Note: ${ }^{* *},{ }^{* *}$ and ${ }^{*}$ indicate that the correlation coefficient is significant at the level of $1 \%, 5 \%$ and $10 \%$ respectively.

Table 4. Mediation effect test.

\begin{tabular}{|c|c|c|c|c|c|c|}
\hline & \multicolumn{3}{|c|}{ Model9 } & \multicolumn{3}{|c|}{ Model 10} \\
\hline & \multicolumn{3}{|c|}{ Sat } & \multicolumn{3}{|c|}{ ROA } \\
\hline & $\begin{array}{l}\text { All the } \\
\text { samples }\end{array}$ & $\begin{array}{l}\text { non-state-owned } \\
\text { commercial Banks }\end{array}$ & $\begin{array}{l}\text { state-owned } \\
\text { commercial } \\
\text { Banks }\end{array}$ & $\begin{array}{l}\text { All the } \\
\text { samples }\end{array}$ & $\begin{array}{l}\text { non-state-owned } \\
\text { commercial Banks }\end{array}$ & $\begin{array}{l}\text { state-owned } \\
\text { commercial } \\
\text { Banks }\end{array}$ \\
\hline PP & $\begin{array}{c}5.076^{* * *} \\
(3.13)\end{array}$ & $\begin{array}{c}4.968^{* * *} \\
(2.74)\end{array}$ & $\begin{array}{c}-1.3748 \\
(-0.79)\end{array}$ & & & \\
\hline Sat & & & & $\begin{array}{l}0.0004 \\
(1.45)\end{array}$ & $\begin{array}{c}0.0005^{*} \\
(1.83)\end{array}$ & $\begin{array}{c}0.002^{* * *} \\
(3.22)\end{array}$ \\
\hline NPL & $\begin{array}{c}-12.2484 \\
(-1.41)\end{array}$ & $\begin{array}{c}-15.9817 \\
(-1.28)\end{array}$ & $\begin{array}{c}-2.7626 \\
(-0.25)\end{array}$ & $\begin{array}{c}-0.21^{* * *} \\
(-7.75)\end{array}$ & $\begin{array}{c}-0.175^{* *} \\
(-5.04)\end{array}$ & $\begin{array}{c}-0.318^{* *} \\
(-7.24)\end{array}$ \\
\hline Size & $\begin{array}{c}-0.0030 \\
(-0.1)\end{array}$ & $\begin{array}{l}0.0591 \\
(1.49)\end{array}$ & $\begin{array}{c}-0.0372 \\
(-0.58)\end{array}$ & $\begin{array}{c}0.001^{* * *} \\
(5.21)\end{array}$ & $\begin{array}{c}0.0003^{* *} \\
(2.92)\end{array}$ & $\begin{array}{c}0.002^{* * *} \\
(6.77)\end{array}$ \\
\hline Time & $\begin{array}{c}-0.0367 \\
(-0.41)\end{array}$ & $\begin{array}{c}-0.2155^{\star} \\
(-1.82)\end{array}$ & $\begin{array}{c}0.453^{* * *} \\
(2.87)\end{array}$ & $\begin{array}{c}-0.001^{* *} \\
(-3.43)\end{array}$ & $\begin{array}{c}-0.0005 \\
(-1.55)\end{array}$ & $\begin{array}{c}-0.0012^{*} \\
(-1.85)\end{array}$ \\
\hline
\end{tabular}




\section{Continued}

\begin{tabular}{|c|c|c|c|c|c|c|}
\hline CAR & $\begin{array}{c}-0.5586 \\
(-0.49)\end{array}$ & $\begin{array}{l}1.8471 \\
(0.53)\end{array}$ & $\begin{array}{c}-2.073^{\star *} \\
(-2.25)\end{array}$ & $\begin{array}{c}0.0094^{\star *} \\
(2.56)\end{array}$ & $\begin{array}{l}0.0149 \\
(1.56)\end{array}$ & $\begin{array}{l}0.0062 \\
(1.61)\end{array}$ \\
\hline fwage & $\begin{array}{c}0.026^{* * *} \\
(2.64)\end{array}$ & $\begin{array}{c}0.0222^{\star} \\
(1.72)\end{array}$ & $\begin{array}{l}0.0200 \\
(1.24)\end{array}$ & $\begin{array}{l}0.0000 \\
(-0.25)\end{array}$ & $\begin{array}{l}0.0000 \\
(-0.47)\end{array}$ & $\begin{array}{l}0.0001 \\
(1.58)\end{array}$ \\
\hline LEV & $\begin{array}{c}-9.034^{\star *} \\
(-2.05)\end{array}$ & $\begin{array}{c}-14.78^{\star *} \\
(-2.32)\end{array}$ & $\begin{array}{c}15.398^{*} \\
(1.88)\end{array}$ & $\begin{array}{c}-0.04^{* * *} \\
(-2.73)\end{array}$ & $\begin{array}{c}-0.0188 \\
(-1.04)\end{array}$ & $\begin{array}{l}-0.0058 \\
(-0.18)\end{array}$ \\
\hline State & $\begin{array}{l}0.1327 \\
(0.63)\end{array}$ & & & $\begin{array}{l}-0.0002 \\
(-0.42)\end{array}$ & & \\
\hline State ${ }^{\star} P P$ & $\begin{array}{c}-4.6037^{\star} \\
(-1.68)\end{array}$ & & & & & \\
\hline State ${ }^{\star}$ Sat & & & & $\begin{array}{c}0.0012^{\star *} \\
(2.03)\end{array}$ & & \\
\hline cons & $\begin{array}{c}8.589^{* *} \\
(2.11)\end{array}$ & $\begin{array}{c}13.305^{* *} \\
(2.21)\end{array}$ & $\begin{array}{c}-14.22 * \\
(-1.77)\end{array}$ & $\begin{array}{c}0.043^{* * *} \\
(3.2)\end{array}$ & $\begin{array}{l}0.0239 \\
(1.39)\end{array}$ & $\begin{array}{l}-0.0072 \\
(-0.22)\end{array}$ \\
\hline $\mathrm{N}$ & 159 & 95 & 64 & 159 & 95 & 64 \\
\hline $\mathrm{F}$ & $3.31^{\star * *}$ & $2.77^{\star \star}$ & $5.02^{\star * *}$ & $24.81^{\star * *}$ & $13.38^{* * *}$ & $15.36^{* * *}$ \\
\hline $\mathrm{R}-\mathrm{sq}$ & 0.1667 & 0.1825 & 0.3857 & 0.5998 & 0.5184 & 0.6576 \\
\hline
\end{tabular}

satisfaction is 5.076 , which is significant at the $1 \%$ level. At the same time, the regression results of model 10 show that the promotion probability has a significant positive promoting effect on the performance of commercial Banks, so it can be preliminarily determined that employee satisfaction has a partial mediating effect. The credible degree in order to further verify the mediation effect, to sobel test data, test results on the level of $10 \%$ rejected the null hypothesis, there is no intermediary effect and the mediation effect accounted for $24.62 \%$ of the overall effect, this means that a promotion incentives to increase employee satisfaction improve the performance of commercial Banks, the results verified the hypothesis 3. Further, this paper divides the sample into state-owned commercial Banks and non-state-owned commercial Banks to explore the mediating role of employee satisfaction in enterprises with different property rights. In model 9 , promotion incentives and salary incentives in non-state-owned commercial Banks can significantly improve employee satisfaction, while in model 10, promotion incentives also significantly improve bank performance. The mediating effect of employee satisfaction can be fully reflected in the sample of non-state-owned commercial Banks. However, in the sample of state-owned commercial Banks, the promotion incentive has little effect on employee satisfaction. The reason for this result may be that, compared with the non-state-owned commercial Banks with obvious market-oriented orientation, the state-owned commercial Banks are mostly government-oriented, and the improvement of employee satisfaction is restricted by the government's control and the rigidity of the internal management of state-owned enterprises, 
which affects the enthusiasm of employees. In addition, the positive promotion relationship between salary incentives and employee satisfaction is more obvious in non-state-owned commercial Banks, because the executives of state-owned commercial Banks are more influenced by political factors, and they would rather give up high salaries than lose their positions in the "system".

\subsection{Robustness Test}

1) Variable substitution. According to Lazear (1981)'s tournament theory, the salary gap is one of the methods to measure the promotion incentive intensity. Therefore, this paper USES the difference between the average salary of the top three executives and the average salary of other executives as the substitution variable of the promotion incentive and brings it into the model test.

2) Endogeneity test. Although the regression results basically verify the hypothesis proposed in this paper, it is worth noting that promotion incentive not only promotes the performance of commercial Banks, but also increases the promotion probability of senior executives. In this paper, Liu et al. (2012) used the industry mean of promotion incentive as an instrumental variable, and adopted two-stage regression to conduct robustness test.

The test results are listed in Table A2 in the Appendix, which is basically consistent with the previous regression. At the same time, the mediating effect of employee satisfaction has been tested by sobel, which is significant at the level of $10 \%$, proving the robustness of the conclusion.

\section{Conclusion}

Based on the principal-agent and psychological contract theories, this paper takes 30 listed commercial Banks from 2009 to 2018 as samples and explores the relationship between promotion incentives, employee satisfaction and performance of commercial Banks through empirical analysis. The main research results are as follows: 1) On the whole, promotion incentive has a positive promoting effect on the performance improvement of commercial Banks, and this driving effect is more obvious in state-owned commercial Banks. 2) Promotion incentive, to some extent, can improve employee satisfaction and thus enhance their efforts. 3) Employee satisfaction plays a part in mediating effect between promotion incentive and performance improvement of commercial Banks. Part of the promotion effect of promotion incentive on bank performance is transmitted through the improvement of employee satisfaction.

The conclusion of this paper is of practical significance for improving the performance of commercial Banks and establishing a more perfect incentive mechanism for commercial bank executives. From this, this paper draws the following enlightenment: first, we should improve the promotion incentive mechanism. As a good substitute for salary incentive and equity incentive, promotion incentive reduces the operation cost of commercial Banks and alleviates the principal-agent problem to some extent. Second, we should attach importance to 
the role of employee satisfaction. Employee satisfaction as a psychological contract can directly affect the level of bank performance, enterprises should establish appropriate incentive mechanism, sound welfare system and construct a harmonious environment to enhance the sense of belonging and identity of employees to the enterprise; Finally, the mechanism of promotion incentive in state-owned commercial Banks is far more complex than that in other Banks, but the effect of promotion incentive is far more effective than that in private Banks. Therefore, the government should adjust the mechanism of agent selection, avoid too much intervention of government regulation, and promote the marketization of executive selection.

There are still shortcomings in this study. Firstly, this study focuses on listed Banks. However, due to the relatively late development of China's stock market, there are only 30 listed Banks with a small number of samples, which may lead to inaccurate conclusions. In addition, it may be inaccurate to measure employee satisfaction by whether or not they are listed on the "best employers in China" list. These problems exist and remain to be solved.

\section{Conflicts of Interest}

The author declares no conflicts of interest regarding the publication of this paper.

\section{References}

Edmans, A. (2011). Does the Stock Market Fully Value Intangibles? Employee Satisfaction and Equity Prices. The Journal of Financial Economics, 101, 621-640. https://doi.org/10.1016/j.jfineco.2011.03.021

Hall, D. T., \& Nygren, S. H. T. (1970). Personal Factors in Organizational Identification. Administrative Science Quarterly, 15, 176-190. https://doi.org/10.2307/2391488

Hertzberg, F. (1959). The Motivation to Work. New York: J. Wiley \& Sons.

Kohn, A. (1993). Why Incentive Plans Cannot Work. Harvard Business Review, September-October, 1-7.

Lazear, E., \& Rosen, S. (1981). Rank-Order Tournaments as Optimum Labor Contracts. Journal of Political Economy, 89, 841-864. https://doi.org/10.1086/261010

Li, H. (2009). Enterprise Incentive Mechanism and Employee's Sense of Belonging. Western China Communications Science \& Technology, No. 7, 111-114.

Liu, G., Cao, Z., \& Zhao, M. (2015). A Study on the Incentive Effect of Employee Income Gap in China's Banking Industry-Based on Different Perspectives of Ownership Nature. Finance and Accounting Monthly, 14, 68-71.

Liu, N., Wang, L., \& Zhang, M. (2012). Government Intervention and Executive Compensation Contracts of State-Owned Enterprises: Empirical Evidence from China. Journal of Chinese Economic \& Business Studies, 10, 391-411. https://doi.org/10.1080/14765284.2012.724983

Maslow, A. (1943). A Theory of Human Motivation. Psychological Review, 50, 370-396. https://doi.org/10.1037/h0054346

Milgrom, P., \& Roberts, J. (1992). Economics, Organization and Management. Upper Saddle River, NJ: Prentice-Hall. 
Shen, C., \& Lin, C. (2012). Why Government Banks Underperform: A Political Interference View. Journal of Financial Intermediation, 21, 181-202.

https://doi.org/10.1016/j.jfi.2011.06.003

Wang, J., \& Kim, T.-Y. (2013). Proactive Socialization Behavior in China: The Mediating Role of Perceived Insider Status and the Moderating Role of Supervisors' Traditionality. Journal of Organizational Behavior, 34, 389-406. https://doi.org/10.1002/job.1811

Xie, J., Fu, L., \& Long, Y. (2019). Relationship between Job Satisfaction and Job Performance of Internet Start-Ups. Enterprise Economy, No. 9, 105-115.

$\mathrm{Xu}, \mathrm{X}$. (2012). Governance Effects of Promotion and Compensation: Effects of the Nature of Property Rights. Economic Science, No. 2, 102-116.

Yu, H., \& Zhang, S. (2016). Promotion Incentive and Evaluation Mechanism of Senior Executives and R \& D Investment of State-Owned Enterprises. Economic Science, No. 5, 95-110.

Zhang, D., Yang, X., \& Zhen, H. (2016). Monetary Compensation, Promotion Incentive and Performance of State-Owned Listed Banks. South China Finance, No. 5, 30-45.

Zhou, M., \& Zhang, Q. (2016). “Face-Saving Project” or "Real Talent and Hard Work"? Research on Innovation of State-Owned Enterprises Inspired by Political Promotion. Management World, 12, 116-132 + 187-188. 


\section{Appendix}

Table A1. Variable definitions table.

\begin{tabular}{|c|c|c|}
\hline Variable name & $\begin{array}{l}\text { Variable } \\
\text { code }\end{array}$ & Variable description \\
\hline $\begin{array}{l}\text { Commercial bank } \\
\text { performance }\end{array}$ & ROA & Return on assets $=$ net profit after tax $/$ total assets \\
\hline Promotion probability & Pro & $\begin{array}{l}\text { The actual promotion value is } 1 \text {, and the unpromoted value } \\
\text { is } 0\end{array}$ \\
\hline Promotion probability & $\mathrm{PP}$ & Regression estimation using logit model \\
\hline Age of an executive & Age & Actual executive age \\
\hline Education background & Edu & $\begin{array}{l}\text { Technical secondary school and below } 1 \text {, college } 2 \text {, } \\
\text { university } 3 \text {, master } 4 \text {, doctor and above } 5\end{array}$ \\
\hline Wage & Wage & Actual wages earned \\
\hline expected executive tenure & Etenture & $\begin{array}{l}\text { Expected tenure of senior management }=(65 \text {-actual age of } \\
\text { senior management })+(\text { average years of service }- \text { years of } \\
\text { service })\end{array}$ \\
\hline Bank Size & Size & Log of total assets \\
\hline $\begin{array}{l}\text { The logarithm of the } \\
\text { bank's Time to market }\end{array}$ & Time & Log of time to market \\
\hline NPL & NPL & $\mathrm{NPL}=$ non-performing loan/total loan balance \\
\hline Capital adequacy ratio & CAR & $\mathrm{CAR}=$ the bank's total capital/risk-weighted assets \\
\hline Capital adequacy ratio & LEV & $\mathrm{LEV}=$ total liabilities/total assets \\
\hline Compensation incentive & Fwage & $\begin{array}{l}\text { The logarithm of the total compensation of the top three } \\
\text { executives }\end{array}$ \\
\hline Employee satisfaction & Sat & $\begin{array}{l}\text { The Banks that enter the "China's best employers of the } \\
\text { year" list were given a value of } 1 \text { and those that did not } \\
\text { were given a value of } 0\end{array}$ \\
\hline
\end{tabular}

Table A2. Robustness test.

\begin{tabular}{|c|c|c|c|c|c|c|c|}
\hline & \multicolumn{4}{|c|}{ Model8 } & Model8 & Model9 & Model10 \\
\hline & \multicolumn{4}{|c|}{ Variable substitution } & \multicolumn{3}{|c|}{ Endogeneity test } \\
\hline & & ROA & & Sat & ROA & Sat & ROA \\
\hline & All & $\begin{array}{c}\text { non-state-owne } \\
\text { commercial } \\
\text { Banks }\end{array}$ & $\begin{array}{c}\text { state-owned } \\
\text { commercial } \\
\text { Banks }\end{array}$ & All & All & All & All \\
\hline PP & & & & & $\begin{array}{c}0.0202^{\star *} \\
(2.57)\end{array}$ & $\begin{array}{c}9.0731^{\star * *} \\
(3.89)\end{array}$ & \\
\hline PP2 & $\begin{array}{l}0.0004 \\
(1.29)\end{array}$ & $\begin{array}{l}0.0003 \\
(0.65)\end{array}$ & $\begin{array}{c}0.0009^{\star *} \\
(2.42)\end{array}$ & $\begin{array}{c}0.5769^{* * *} \\
(3.97)\end{array}$ & & & \\
\hline Sat & & & & & & & $\begin{array}{c}0.0007^{* * *} \\
(3.00)\end{array}$ \\
\hline NPL & $\begin{array}{c}-0.085^{\star * *} \\
(-2.77)\end{array}$ & $\begin{array}{c}-0.172^{\star * *} \\
(-3.35)\end{array}$ & $\begin{array}{c}-0.0409 \\
(-0.99)\end{array}$ & $\begin{array}{c}-13.9939^{*} \\
(-1.69)\end{array}$ & $\begin{array}{c}-0.238^{\star * *} \\
(-9.16)\end{array}$ & $\begin{array}{c}-18.848^{*} \\
(-1.95)\end{array}$ & $\begin{array}{c}-0.2116^{* * *} \\
(-8.82)\end{array}$ \\
\hline Size & $\begin{array}{c}0.0004 \\
(0.54)\end{array}$ & $\begin{array}{c}-0.0033^{\star *} \\
(-2.52)\end{array}$ & $\begin{array}{c}-0.0032^{*} \\
(-2.32)\end{array}$ & $\begin{array}{c}-0.0039 \\
(-0.13)\end{array}$ & $\begin{array}{c}0.0005^{* * *} \\
(4.66)\end{array}$ & $\begin{array}{c}0.0035 \\
(0.11)\end{array}$ & $\begin{array}{c}0.0005^{* * *} \\
(4.7)\end{array}$ \\
\hline
\end{tabular}




\section{Continued}

\begin{tabular}{|c|c|c|c|c|c|c|c|}
\hline Time & $\begin{array}{c}-0.0001 \\
(-0.4)\end{array}$ & $\begin{array}{c}-0.0001 \\
(-0.18)\end{array}$ & $\begin{array}{l}0.0010 \\
(1.72)\end{array}$ & $\begin{array}{c}-0.0499 \\
(-0.57)\end{array}$ & $\begin{array}{c}-0.001^{* * *} \\
(-3.45)\end{array}$ & $\begin{array}{c}-0.0842 \\
(-0.92)\end{array}$ & $\begin{array}{c}-0.0009^{\star * *} \\
(-2.96)\end{array}$ \\
\hline CAR & $\begin{array}{c}0.0002 \\
(0.11)\end{array}$ & $\begin{array}{c}-0.0069 \\
(-0.5)\end{array}$ & $\begin{array}{c}-0.0017 \\
(-1.04)\end{array}$ & $\begin{array}{c}-0.5473 \\
(-0.49)\end{array}$ & $\begin{array}{c}0.0091^{\star * *} \\
(3.99)\end{array}$ & $\begin{array}{l}0.0225 \\
(0.03)\end{array}$ & $\begin{array}{c}0.0085^{* * *} \\
(3.37)\end{array}$ \\
\hline fwage & $\begin{array}{l}0.0000 \\
(0.46)\end{array}$ & $\begin{array}{l}0.0001 \\
(0.45)\end{array}$ & $\begin{array}{c}0.0003^{* *} \\
(2.38)\end{array}$ & $\begin{array}{c}0.1673^{* * *} \\
(4.2)\end{array}$ & $\begin{array}{l}0.0000 \\
(0.71)\end{array}$ & $\begin{array}{c}0.0305^{* *} \\
(2.52)\end{array}$ & $\begin{array}{l}0.0000 \\
(-0.2)\end{array}$ \\
\hline LEV & $\begin{array}{c}-0.063^{* * *} \\
(-4.8)\end{array}$ & $\begin{array}{c}-0.052^{\star * *} \\
(-2.83)\end{array}$ & $\begin{array}{c}-0.0470^{* *} \\
(-2.53)\end{array}$ & $\begin{array}{c}-10.4924^{\star *} \\
(-2.44)\end{array}$ & $\begin{array}{c}-0.043^{* * *} \\
(-2.99)\end{array}$ & $\begin{array}{c}-10.015^{\star *} \\
(-2.36)\end{array}$ & $\begin{array}{c}-0.0341^{\star *} \\
(-2.36)\end{array}$ \\
\hline State $^{\star}$ pp 2 & $\begin{array}{l}-0.0003 \\
(-1.43)\end{array}$ & & & $\begin{array}{c}-0.1247^{*} \\
(-1.79)\end{array}$ & & & \\
\hline State & & & & $\begin{array}{l}-0.2457 \\
(-1.56)\end{array}$ & $\begin{array}{c}-0.0002 \\
(-0.38)\end{array}$ & $\begin{array}{c}-0.254^{*} \\
(-1.79)\end{array}$ & $\begin{array}{l}0.0002 \\
(0.64)\end{array}$ \\
\hline cons & $\begin{array}{c}0.0664^{* * *} \\
(6.54)\end{array}$ & $\begin{array}{c}0.1000^{\star * *} \\
(5.59)\end{array}$ & $\begin{array}{c}0.1045^{\star * *} \\
(5.64)\end{array}$ & $\begin{array}{c}10.2057^{\star *} \\
(2.57)\end{array}$ & $\begin{array}{c}0.0453^{\star * *} \\
(3.56)\end{array}$ & $\begin{array}{c}9.2805^{\star *} \\
(2.35)\end{array}$ & $\begin{array}{c}0.0381^{* * *} \\
(2.93)\end{array}$ \\
\hline $\mathrm{N}$ & 159 & 95 & 64 & 159 & 159 & 159 & 159 \\
\hline chi2 2 & & & & & $287.11^{\star * *}$ & $36.83^{* * *}$ & $246.15^{* * *}$ \\
\hline F & $32.12^{* * *}$ & $12.84^{* * *}$ & $42.13^{* * *}$ & $4.64^{\star * \star}$ & & & \\
\hline $\mathrm{R}-\mathrm{sq}$ & 0.8087 & 0.7528 & 0.9335 & 0.2190 & 0.5547 & 0.0480 & 0.5887 \\
\hline
\end{tabular}

